\title{
ARTIFICIAL INTELLIGENCE IN ENGINEERING AS A FACTOR INFLUENCING A CHOICE OF STUDIES AT VOCATIONAL SCHOOL AND FUTURE CAREER IDEAS OF STUDENTS
}

\author{
Josef Malach and Dana Vicherková \\ Departrment of Education and Adult Education \\ University of Ostrava, Frani Sramka 3, Ostrava, the Czech Republic, 70900
}

\begin{abstract}
As regards the field of mechanical engineering, artificial intelligence covers the use of digital technology, automation and robotisation and creates conditions for the digital connection of production processes, which has been called the fourth industrial revolution, and all such functioning processes represent Industry 4.0. Nowadays, global producers of mechanical engineering technology offer the so-called smart technologies, covering all kinds of modern technologies for metal machining, which are at the heart of every industrial production. The aim of this study was to examine whether the current possibilities of automation and robotisation as components of artificial intelligence in the engineering production influence the choice of a secondary school in primary school pupils and the extent of pupils' preference to apply digital technologies in the engineering production in their future work. The study also investigated whether respondents' answers are influenced by the year of study at secondary school and their subjectively assessed level of digital competences. The analysis of answers from 320 pupils from two secondary mechanical engineering schools showed that almost $40 \%$ of pupils were positively influenced by the possibilities of automation and robotisation in the engineering production and $70 \%$ of respondents wish their work would be related to the application of digital technologies in the engineering production to at least a certain extent. Using the chi-squared test, we found out that the motivation when choosing a secondary school based on the possibility to use automation and robotisation in the engineering production has a significant impact on students' wish to work with digital technologies in their future work. The same test also proved a significant dependency between pupils' self-assessment of digital competences and their wish to use digital technologies in their future work.
\end{abstract}

\section{KEYWORDS}

Artificial Intelligence, Choice of Studies, Career Ideas, Secondary Mechanical Engineering School

\section{INTRODUCTION}

Mechanical engineering, like other fields, is undergoing the fourth industrial revolution. It is connected with processes of a broader and more complex usage of digital technologies which enable to automate and robotise the production process as well as its preceding and following stages (development, logistics, promotion and sale). The production organised in such a way is called Industry 4.0 or digital economy (Gekara, Snell, Molla, Karanasios \& Thomas, 2019).

\subsection{Digital Economy and Digital Competence}

Collecting, processing, distribution and usage of a large amount of data for the management (before/after) of production stages already requires elements of artificial intelligence. Digital economy requires highly educated ICT specialists as well as general workforce with necessary digital competencies. Research carried out using a large number of methods in more than 400 Australian organisations from four resorts showed that "more than half of the industry survey respondents were not satisfied with the digital skills of their vocational and educational training (VET) and graduate recruits had concerns about the adequacy of VET qualifications in meeting industry skills requirements" (Gekara et al., 2019 p. 3). Therefore, it can be assumed that the results of this representative research would be similar in other countries, including the Czech Republic. Gathering, justifying and specifying 
the requirements for the digital literacy, competency or skills is the aim of many creators using general frameworks of digital competencies (DigComp 2.0 and others) or specific frameworks for certain professions (e.g. teachers - DigCompEdu, UNESCO ICT competency framework for teachers, DigCompTeach).

\subsection{Domains of Digital Skills}

An example of a broader definition of digital skills has been provided by the World Economic Forum (WEF, 2016), which identified and detailed eight different digital skills domains: use, identity, literacy, rights, communications, emotional intelligence, security and safety. The suggestion is that, in a mature digital society, digital skills and knowledge must be equally developed across these domains, leading to an established digital culture where most people are competent, comfortable, confident and safe in their daily navigation of digital work and life environment. (Gekara et al, 2019, p. 19.) The reaction of Australian authors to the WEF model was that they adopted a broad definition of digital skills as a combination of the following five areas:

1. digital knowledge (theoretical comprehension and understanding)

2. cognitive know-how (involving the use of logical, intuitive, innovative and creative thinking in the digital space)

3. practical know-how (including the use of digital tools such as hardware, software, information and security systems)

4. Competence (ability to learn, adapt and apply digital knowledge in new settings)

5. "digital" attitude (value and beliefs).

After discussions with employers, these areas were transformed into a form of digital skills requirements in the Australian workforce. (Figure 1).

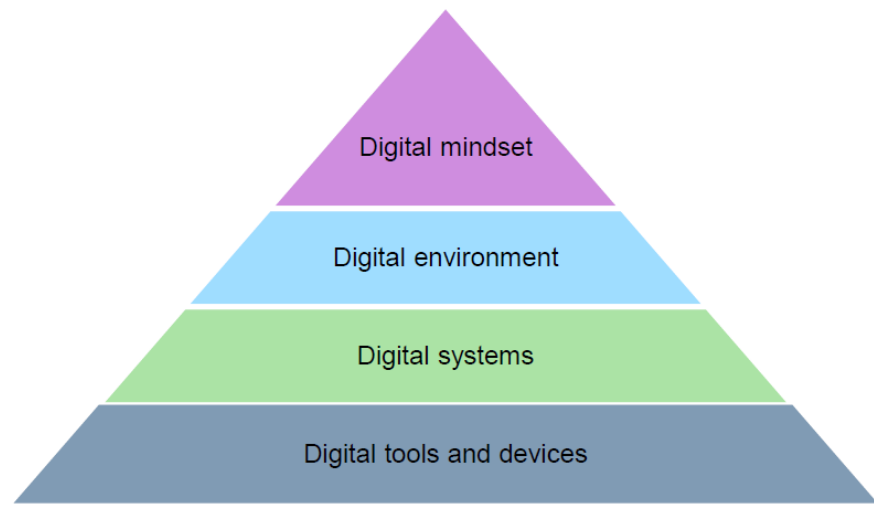

Figure 1. Categories of digital skills requirements Source: Gekara et al., 2019 p. 24

It is worth noting the first two levels of the employer requirements model, which formulates the requirements and abilities of a working individual to move and purposefully act in a constantly changing and enriching digital environment, and a digital mindset, which creates the preconditions for creative and innovative problem-solving connected with the digitalisation of industry and services.

\subsection{Requirements for Digital Competences}

If we look at the requirements for employees' digital competences, Australian employers primarily require the mastering of five main technologies: mobile, cloud, big data and Internet of things. Less than one-fourth of respondents identified emerging technologies, such as drones, wearables, self-driving vehicles and augmented and virtual reality (Gekara, 2019, p. 21).

The above-mentioned requirements of present-day employers for general digital literacy of employees from selected resorts can be viewed as external incentives which could attract younger workers born after 2000 into many fields, the so-called digital generation which grew up in the digital environment and uses digital tools for learning, communication and fun. 
The $21^{\text {st }}$-century children form such a specific category that apart from a very fitting name, they are associated with four main topics: physical health, emotional well-being, digital technologies and peers and families (Burns, 2019). The theme of digital technologies is then divided into a digital divide, information as power, social networks and cyber risks. These four themes are interrelated, and they also interact with broader societal trends (Gekara, 2019, p. 20).

Therefore, it could be presupposed that the $21^{\text {st }}$-century children will choose their professional path also based on whether and how much they can apply their digital knowledge, skills and attitudes, which can develop into "digital needs".

\subsection{Digital Needs}

We introduce the term "digital needs" to describe individuals' efforts to attain a level of digital literacy ensuring their good employability in the labour market and efficient usage in their personal lives.

Completely new phenomena and their risks or benefits for the digital society have been described, for instance, "digitally excluded people" (Good Things Foundation \& Yates, 2017) or "digital disruption" (Gekara, 2019 , p. 21). The so-called "disruptive technologies" include, for example, Airbnb, Uber, Grab and increasingly prevalent shared workspaces.

We suppose that the usage of young people's digital needs in the following level of education can be a significant factor influencing their choice of the field of study or a given school. The connection between studies and subsequently a professional life can be regarded as a certain part of the "digital attitude", since the results of the international survey secondary analysis ICILS 2013 and PISA 2012 showed that Czech pupils use a computer for leisure purposes at a high rate in international comparisons, and even at the highest rate in the OECD countries (ČŠI, 2016, s. 2). The PISA survey showed that 15 -year-old Czech pupils spend 120 minutes online with technologies per day and up to 150 minutes at weekends. It also demonstrated that pupils who use a tablet or notebook at schools use these tools for school purposes more often than their peers who use desktop computers at school. It can also be paradoxical that pupils from less successful schools use a computer for various purposes more often than pupils from very successful schools. The differences are higher in grammar schools than in primary schools.

As for the computer usage at home, pupils from less successful grammar schools use a computer for entertainment activities (e.g. playing games), on the other hand, pupils from very successful grammar schools do more intellectual activities (e.g. reading news, preparation for school). The frequency of the ICT usage by pupils from individual schools is inversely proportional to the success rate of these schools in the PISA Mathematics test, which emphasises "the need for caution when introducing new technologies at schools" (ČŠI, 2016, s. 3).

Therefore, it is possible to state that it is not realistically appropriate to develop a "global" non-specific need to apply ICT in people's lives, but mainly individual and particular digital needs which are related to the professional, civil or economic application of ICT. Thus, we can discover terms such as "study digital needs" or "professional digital needs", and their content can become the subject of subsequent studies.

\subsection{The Potential of ICT to increase the Quality of Education}

It is not possible to solely rely on the effects of informal incidental education of children and pupils in how to use digital tools, but it is necessary to cultivate digital literacy, including digital needs purposefully, thoughtfully and systemically (Strategie digitálního vzdělávání, 2014, Analýza systémů a nástrojů pro podporu cíleného rozvoje digitální gramotnosti, 2018). The European Commission emphasises this fact referring to previous documents by stating that training and education systems [should] be 'fit for the digital age' (European Commission, 2018).

The thematic report of the Czech School Inspectorate (2018) in the school year 2016/2017 summarises the result of their investigation: The expected success rate in the test of information literacy was set at $67 \%$ (pupils who correctly solved more than three-thirds of questions). While primary school pupils did not reach this level more often $(63 \%)$, pupils from secondary schools with the maturita school-leaving exam got closely under this level (66\%). Pupils from secondary grammar schools reached the average success rate in the test $71.1 \%$ (with $58 \%$ girls) and pupils from technical fields of study (including mechanical engineering and engineering production) $67.5 \%$ (with $13 \%$ girls). 
A recent similar report from the Czech School Inspectorate (2019) in the school year 2018/2019 states that the field of ICT (digital technologies) was fully included in the development concept at more than $70 \%$ of secondary schools visited during the thematic inspection activity. Although the majority of teachers in approximately three-fourths of secondary schools are aware of the ICT potential to increase the quality of education and more and more teachers include these technical tools in their teaching, only one-fourth of teachers from the visited schools feel confident and methodically very competent working with ICT. As for the specific usage of digital technologies in teaching, secondary schools mainly focus on various teaching activities (66\%), including project teaching, less frequently on the complex integration of digital technologies into the teaching process and the exploration of new and effective approaches (33\%). Pupils were mostly able to work with ICT autonomously; however, their active participation (except for ICT classes) was required relatively rarely. By contrast, the use of ICT for teacher's own teaching presentation prevailed. The analysis of the ICT usage at schools did not find that schools had used the quality of ICT equipment, teachers' experience with using ICT in teaching or methodical integration of ICT into teaching of all subjects and into improving the culture for the purposes of attracting new students, in other words, the decision of primary school pupils to study at a given secondary school.

\section{THE CHOICE OF A FURTHER EDUCATION PATH}

The needs of the Society 4.0 or the Digital Society can be fulfilled by employees of many professions characterised by national qualification frameworks. Formal qualification requires obtaining entry education and/or qualification courses or training. The projected developments of the workforce suggest that more professions will disappear and the need for new ones will appear in the next few years. The education system usually reacts to requirements of the industry with a certain delay due to the retardant influence of (education) policy and financing of innovations. Nonetheless, in recent years, we can notice activities examining the factors and motivations leading to the choice of a further education path, especially in primary school pupils. These surveys should provide useful data for the management of secondary schools and their authorities, industrial clusters, economic chambers, employers and decision bodies.

\subsection{Factors Influencing the Choice of a Secondary School}

At schools, the factors influencing the choice of a secondary school are essential data for the work of education (career) advisors, and as regards our focus, on the influence of automation and robotisation processes in the engineering production on the choice of a secondary technical school, it also concerns the school ICT coordinators and teachers of technical subjects. Although, the ICT coordinators have their defined professional standard (Malach, Kostolányová, 2017), in a recent analysis of their work (Česká školní inspekce, 2019, s. 15), $87 \%$ of them stated that teachers most often turn to them when they need to solve technical problems in teaching and approximately $60 \%$ of ICT coordinators stated that teachers also often ask them for recommendations or consultations regarding the usage of suitable software or hardware for teaching. Only approximately $30 \%$ of coordinators stated that teachers most often turn to them to consult didactic methods for the usage of digital technologies in teaching. It has been found that the vision of the ICT usage had been fulfilled in only $16 \%$ of schools. The ICT coordinators are its "spiritual leaders", but they are not the only promoters and assistants able to help others. It has not been noted that the coordinator had somehow co-created the image of the secondary school as an institution fully using its ICT equipment for the fulfilment of its main activities, especially education and qualification activities.

In a survey focusing on the choice of an education path, the question asking why they selected their field of study, $51 \%$ of respondents answered that it was the interest in the field, $12 \%$ with regard to their friends' experience and $12 \%$ due to good employability. $4 \%$ of respondents stated that their choice was influenced by the fact that it was a "good school" and $7 \%$ said that it was because "parents wanted it" (Trhlíková, Vojtěch a Úlovcová, 2008).

In 2011, 40 primary schools and 20 secondary schools were examined in a survey focusing on the family and peer influence on the education path, factors influencing the choice of the education/professional path and views on the choice of a given school and profession. Factors which could influence the choice of the education/profession path included the use of the Internet as a source of information. However, it was not the 
ICT usage, or digital technologies as learning tools or later work aids or tools, that could influence this choice. For primary school pupils, the Internet is the second (after parents) most used source of information ( $83.3 \%$ of pupils mentioned it), as for the pupils from secondary schools, it is the most frequently mentioned source of information (72.6\% pupils mentioned it). Many pupils acquire information directly from the school to which they apply, where primary school pupils do it more often ( $82.6 \%$ of pupils) than secondary school pupils (56.7\% of pupils).

In 40 primary schools, they examined the use of information sources for pupils' decision about their further studies and work (Hlad'o, Drahoňovská, 2012) and the Internet as one of the sources was directly observed. Out of almost 800 pupils, $93.9 \%$ used it, and it was in the third place of sources after family members and the school to which pupils apply. In the majority of cases, it is the information from the Internet that helps pupils from secondary vocational schools to decide about their further education and future profession. The Internet provided information for the choice of further education and professional path to $85 \%$ of pupils.

\subsection{Barriers to Entry in Secondary Mechanical Engineering Schools}

During the analysis of primary school pupils' barriers to entry in technical education, the barriers were grouped into barriers on the national level (system, financial or practical barriers) and barriers on the level of teachers, schools, pupils and parents (Trexima, 2015). On the level of teachers, the barriers represent mainly the insufficient development of digital competences and informatics thinking of teachers, the lack of willingness to use technology in a natural way; it means how it is commonly projected into other fields. The important issue is not only the school equipment itself but also the inventiveness in the usage of available equipment, especially the usage of open electronic education sources. It has been identified that the barrier on the level of schools was the lack of access to digital technologies and other devices to support the development of pupils' technical skills. The situation is made worse by the lack of organisational support which leads to the absence of a functional and effective timetable of specialised rooms which are thus often inaccessible.

Available analyses and surveys show that the Internet plays a prominent role in primary school pupils' decision processes about their further education path and secondary school pupils' decisions about their further education path or employability. Nevertheless, we did not find information about whether the possibilities of automation and robotisation of the engineering production acted as a factor in their decision, in other words, these factors probably exist in a latent form and it is not possible to extract them from the "interest-in-the-field" factor without investigations. Also, there are no data about whether pupils of mechanical engineering fields wished their future work was connected with the application of digital technologies.

\section{RESEARCH}

The research on a sample of pupils from two secondary schools studying mechanical engineering in the Moravian-Silesian region in the Czech Republic was carried out at the end of 2019. Using a questionnaire, we received data from 320 respondents who attended all four years of studies. The majority of respondents were boys $(98.13 \%)$, which is usual in these fields.

The questionnaire consisted of 41 items focused on five areas:

1. respondents identification (8 items)

2. motivation to career choices ( 8 items)

3. interest in engineering (8 items)

4. learning strategies (10 items)

5. digital technology use (7 items)

For this study, three scaling items were selected from the questionnaire.

1. To what extent did current possibilities of automation and robotisation of the engineering production influence your choice to study at a given secondary mechanical engineering school (proposed answers: a) never, b) very little, c) only to a certain extent, d) very much and e) fundamentally). (Question 35)

2. Do you wish your future work would be connected with the application of digital technologies in the engineering production (proposed answers: a) not at all, b) only limitedly, c) to a certain extent, d) rather yes, e) very much). (Question 40) 
3. As for my level of digital competences, I consider myself to be a) a total beginner, b) a beginner, c) a informed user, d) a user of main programming tools and e) a user of specific engineering applications. (Question 41)

Information about pupils' gender and year of study were available.

\subsection{Research Aims}

The research aim was to find answers to the following research questions:

1. To what extent do current possibilities of automation and robotisation of the engineering production influence pupils' choice to study at a given secondary mechanical engineering school?

2. To what extent do secondary school pupils wish their future work was connected with the application of digital technologies?

3. How do pupils subjectively feel about their level of digital literacy?

4. Is there a correlation between the impact of automation and robotisation of the engineering production on the choice of the field of study and pupils' wish to apply digital technologies in their work?

5. Is the choice of studies and wishes regarding their work influenced by their subjectively declared level of digital competences?

6. Is the correlation between the choice of studies, wishes regarding their work and the level of pupils' digital competences influenced by the duration of their studies at secondary school (the year of studies)?

\section{RESULTS}

Data were processed using the MS Excel spreadsheet programme. The results are presented in the form of charts and tables in the text bellow.

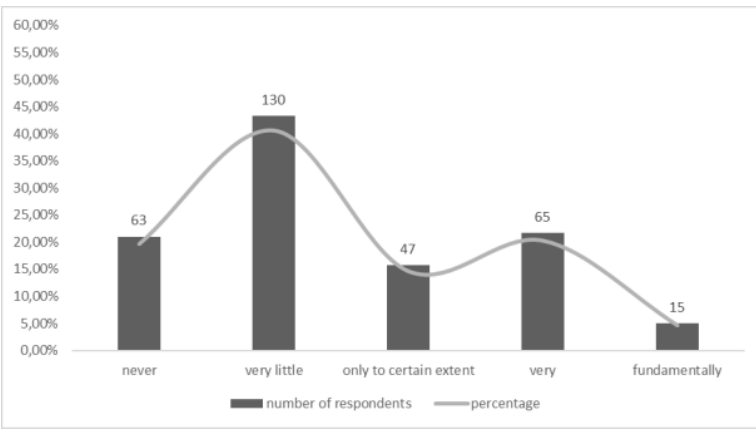

Figure 2. Q35 To what extent did the current possibilities of automation and robotisation influence the choice of a given school

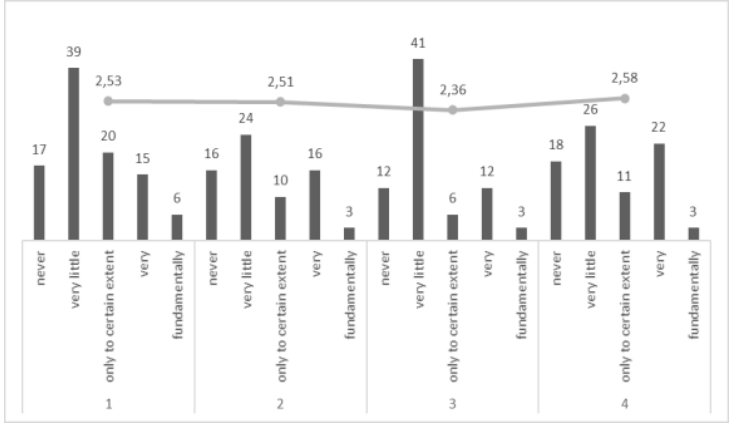

Figure 3. Q35 According to the year of study

\section{Source: Own}

Figure 2 shows the distribution of answers to the question "To what extent did the current possibilities of automation and robotisation of the engineering production influence the choice to study at a given secondary mechanical engineering school."

The answers show that about $60 \%$ of respondents evaluate the possibility of automation as a very little or no motivating factor at all.

Figure 3 shows the distribution according to the year of study. In addition, the arithmetic mean for each year of study is calculated, where the answer "not at all" is equal to one and the answer "very much" is equal to five. It is therefore clear that there was no change in motivation across years and the possibility of automation is rather a weaker motivation factor. 


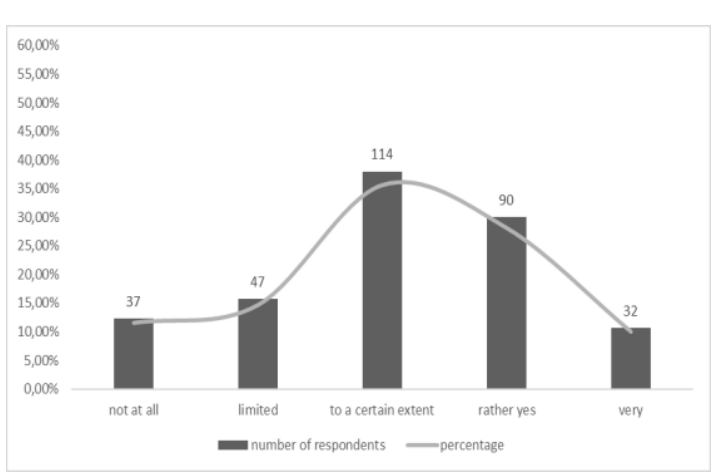

Figure 4. Q40 To what extent do respondents want to link their future to digital technology applications in mechanical engineering

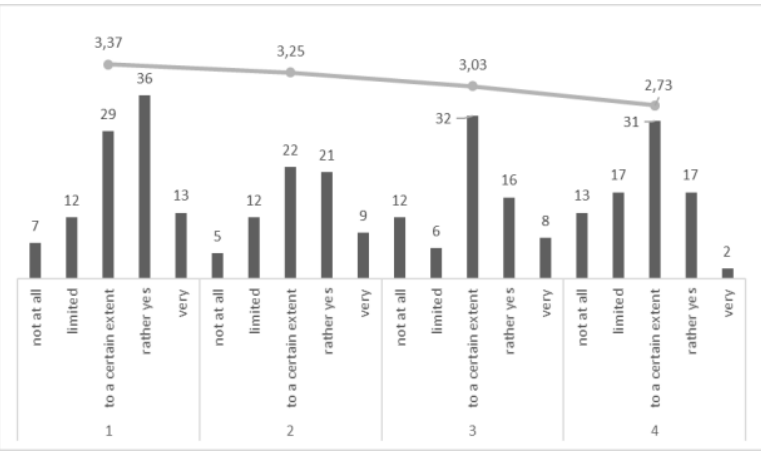

Figure 5. Q40 According to the year of study

\section{Source: Own}

Figure 4 outlines the distribution of responses how much the respondents want to link their future to digital technology applications in mechanical engineering.

Over $70 \%$ of respondents expect, at least to a certain extent, to apply digital technology in the future.

Figure 5 shows the individual distribution according to years. While in the first year the average is 3.37 , in the following years a gradual fall to a value of 2.73 is observed. Whether behavioural factors influenced this development is for further investigation.

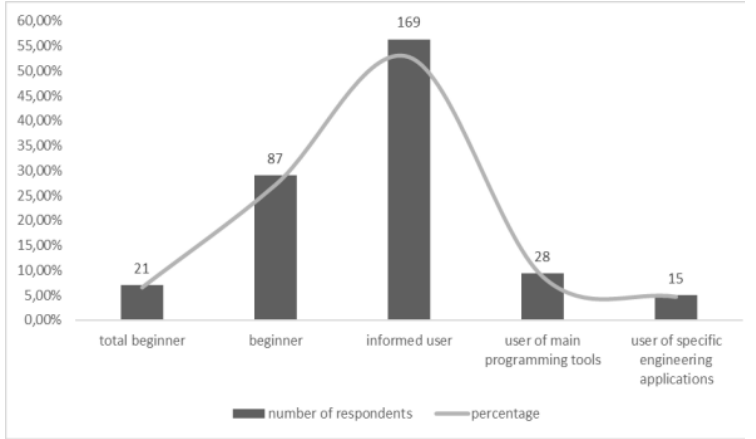

Figure 6. Q41 Subjectively declared level of pupils' digital competences

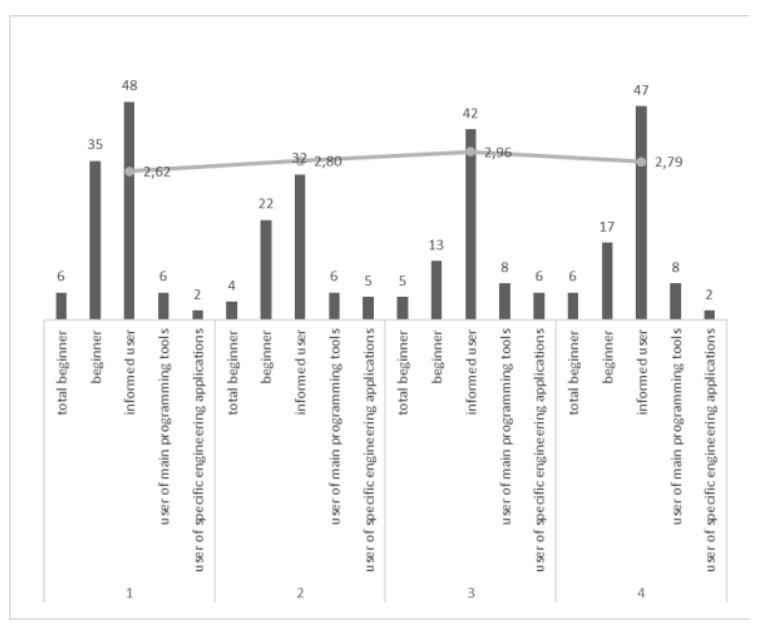

Figure 7. Q41 According to the year of study

Source: Own

Question 41 is aimed at the self-assessment of the acquired level of their digital skills. Almost $80 \%$ of respondents evaluate themselves as beginners and educated users.

The average value of the self-assessment rises from the first to the third year and decreases slightly in the fourth year. The rating is always slightly below the average "informed user" rating.

In this section, the answers were grouped into three categories - below average, average, above average.

The survey examined three basic hypotheses and their source data and the calculated Pearson's chi-squared can be found in Table 1, 2 and 3.

Table 1 presents source data and the calculated Pearson's chi-squared for the verification of hypothesis H1 about the relation between questions 35 and 40 . 
Table 1. Answers to questions no. 35 and 40 and the value of Pearson's chi-squared

\begin{tabular}{|l|c|c|c|c|}
\hline Significance: (p) & $\mathbf{0 . 0 0 2}$ \\
\hline Q35/Q40 & not at all/only limitedly & to a certain extent & rather yes/very much & Total \\
\hline never/very little & 54 & 77 & 62 & 193 \\
\hline only to a certain extent & 6 & 11 & 30 & 47 \\
\hline very much/fundamentally & 24 & 26 & 30 & 80 \\
\hline Total & 84 & 114 & 122 & 320 \\
\hline
\end{tabular}

Source: Own

On the standard level of significance, we reject the zero hypothesis because $0.05>0.002$ and we accept the alternative hypothesis, that is to say, there is a dependency between question Q35 and Q40. The more students were influenced by the state of automation and robotisation when choosing their school, the more they wish to apply digital technologies in their future work.

Table 2 presents source data and the calculated Pearson's chi-squared for the verification of hypothesis $\mathrm{H} 2$ about the relation between questions 35 and 41 .

Table 2. Answers to questions no. 35 and 41 and the value of Pearson's chi-squared

\begin{tabular}{|l|c|c|c|c|}
\hline Significance: (p) & $\mathbf{0 . 0 6 9}$ & \multicolumn{2}{l|}{} \\
\hline Q35/Q41 & total beginner /beginner & informed user & advanced user & Total \\
\hline never/very little & 73 & 102 & 18 & 193 \\
\hline only to a certain extent & 12 & 26 & 9 & 47 \\
\hline very much/fundamentally & 23 & 41 & 16 & 80 \\
\hline Total & 108 & 169 & 43 & 320 \\
\hline
\end{tabular}

\section{Source: Own}

On the standard level of significance, we do not reject the zero hypothesis because $0.05<0.069$ and we accept the alternative hypothesis, that is to say, there is no dependency between question Q35 and Q41.

Therefore, it cannot be stated that there is a dependency between the level of pupils' self-assessment of digital competences and how much they are influenced by the current possibilities of automation and robotisation of the engineering production when choosing a secondary mechanical engineering school.

Table 3 presents source data and the calculated Pearson's chi-squared for the verification of hypothesis H3 about the relation between questions 41 and 40 .

Table 3. Answers to questions no. 41 and 40 and the value of Pearson's chi-squared

\begin{tabular}{|l|c|c|c|c|}
\hline Significance: (p) & $\mathbf{0 . 0 0 5}$ & & \\
\hline Q41/Q40 & not at all/only limitedly & to a certain extent & rather yes/very much & Total \\
\hline total beginner/beginner & 41 & 35 & 32 & 108 \\
\hline informed user & 36 & 66 & 67 & 169 \\
\hline advanced user & 7 & 13 & 23 & 43 \\
\hline Total & 84 & 114 & 122 & 320 \\
\hline
\end{tabular}

Source: Own

On the standard level of significance, we reject the zero hypothesis because 0,05 $>0,005$ and we accept the alternative hypothesis, that is to say, there is a dependency between question Q41 and Q40. Therefore, it can be stated that there is a dependency between the level of pupils' self-assessment of digital competences and their wish to apply digital technologies in their future work.

Figure 8 shows individual correlations between questions, i.e. how consistent the answers remained to the questions. The lowest correlation was between the motivation to study at school and the evaluation of their digital skills, while the highest correlation was between the motivation to study at school with automation and robotisation and the practical use of digital technology in their future work. 


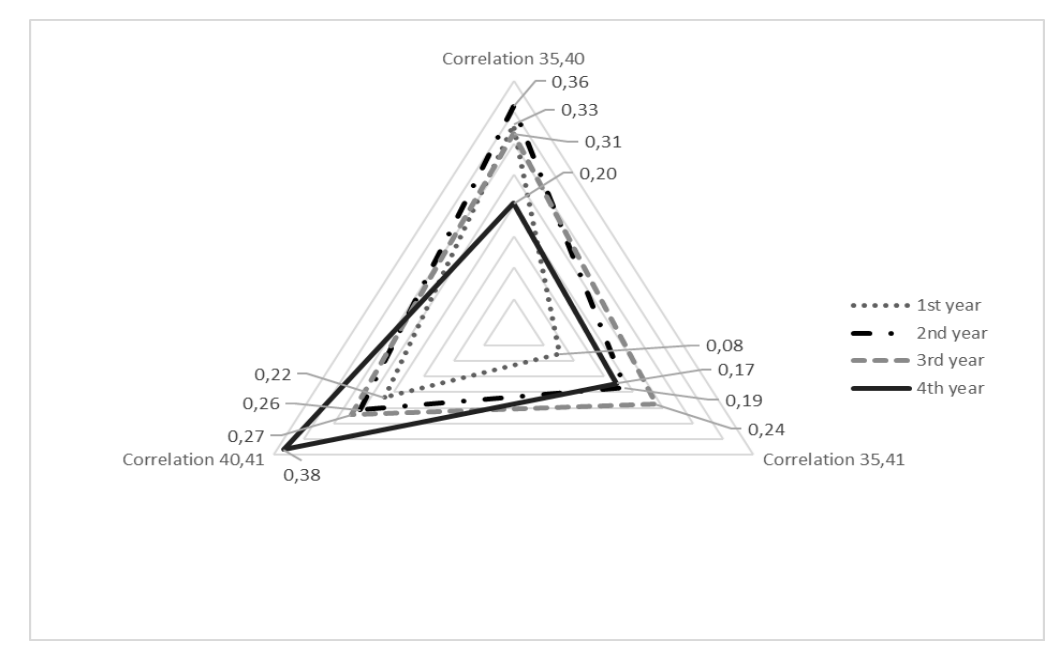

Figure 8 . The correlation between data of the three questionnaire items according to the year of study Source: Own

\subsection{Summary of Key Research Results}

In accordance with the formulated research questions, the research results can be formulated in the following way:

1. The current possibilities of automation and robotisation of the engineering production did not influence or influenced only very little (60\% of answers) primary school pupils' choice to study at a given secondary mechanical engineering school. On the other hand, this fact was to a certain extent, very much or fundamentally important for $40 \%$ of pupils. In this case, we did not notice significant differences between years of study.

2. Almost three-fourths of secondary school pupils wish to apply digital technologies in their future work. In the fourth year of study, the proportion of these pupils falls to $62 \%$.

3. Pupils' subjectively assessed level of digital literacy has the characteristics of a normal distribution. More than one-half of pupils consider themselves to be informed users and $14 \%$ of pupils use the majority of common programming tools or specific applications.

4. It has been proved that the more students were influenced by the state of automation and robotisation when choosing a school, the more they wish to apply digital technologies in their future work.

5. We have not observed any dependency between the influence of current possibilities of automation and robotisation when choosing a school and pupils' level of digital competences.

6. It has been proved that there is a dependency between the level of pupils' self-assessment of digital competences and their wish to use digital technologies in their future work. The highest correlation between these variables has been noted in pupils from the last year of study.

\section{DISCUSSION AND CONCLUSION}

Given that we are not aware of any studies which would examine the influence of automation and robotisation as elements of artificial intelligence on the choice of the education path, or studies examining whether students wish to work in a technical profession integrating digital technologies, it is not possible to assess whether the findings from the research sample have a broader validity. However, the research continues in more secondary schools and thus, it could be possible to generalise its outputs.

Research findings can be used in career counselling, which should better accentuate the links between studies at secondary technical schools and requirements for the application of artificial intelligence in the engineering production. Secondary school curricula should better react to the development of adolescents' "digital needs" and use marketing tools to appropriately direct them towards the awakening of "professional digital needs", which the school is capable of satisfying using its equipment and quality of teaching. Students' 
potential employers should emphasise in their human resources management system that engineering production, both today and in the future, is inherently related to digital technology. Corporate recruitment tools for recent secondary school graduates should be modified to reflect this reality.

\section{ACKNOWLEDGEMENT}

This study was written within a research project of the Technology Agency of the Czech Republic called "Education in engineering and its optimisation for the needs of the labour market", reg. TJ 02000083.

\section{REFERENCES}

Burns, T., 2019. Childhood in the digital age. In Burns, T., \& Gottschalk, F. (eds.) Educating 21 st century children. Emotional well-being on the digital age. Paris: OECD Publishing, 17-32.

Česká školní inspekce, 2019. Rozvoj informačni gramotnosti na střednich školách ve školním roce 2018/2019. Tematická zpráva. Praha: ČS̆I, [listopad 2019].

Česká školní inspekce, 2018. Rozvoj informační gramotnosti na základních a střednich školách ve školním roce 2016/2017. Tematická zpráva. Praha: ČŠI, [červen 2018].

Česká školní inspekce, 2016. Žáci a ICT. Sekundárni analýzy výsledků mezinárodních šetření ICILS 2013 a PISA 2012. Praha: ČŠI, [květen 2016].

European Commission. Communication from the Commission to the European parliament, the Council, the European economic and social committee and the Committee of the regions on the Digital Education Action Plan. $\{\mathrm{SWD}(2018)$ 12 final \}. Brussels, [17. 1. 2018].

European Digital Competence Framework for Teachers. INTEF (2017). Available at:

https://www.slideshare.net/educacionlab/common-digital-competence-framework-for-teachers

European Framework for the Digital Competence of Educators (DigCompEdu). Available at: https://ec.europa.eu/jrc/sites/jrcsh/files/digcompedu_overview_-_english.pdf

Fond dalšího vzdělávání, 2018. Analýza systémů a nástrojů pro podporu cíleného rozvoje digitální gramotnosti. Praha: Ministerstvo práce a sociálních věcí, [leden 2018].

Gekara, V., Snell, D., Molla, A., Karanasios, S., \& Thomas, A., 2019. Skilling the Australian workforce for the digital economy. Adelaide: Natinal Centre for Vocational Education Research. ISBN 978-1-925717-30-3.

Good Things Foundation \& Yates, S., 2017. The real digital divide? Understanding the demographics of non-users and limited users of the internet: an analysis of Ofcom data, [June 2017].

Malach, J., Kostolányová, K., 2017. School as Digitally Competent Educational Organization: Specific Preparation for Work Positions and Educational Roles. In: 16 th European Conference on eLearning: Proceedings of the 16 th European Conference on eLearning 2017 Porto. Reading: Academic Conference and Publishing International Limited, 344-352. ISBN 978-1-911218-59-3.

MŠMT, 2014. Strategie digitálního vzdèlávání do roku 2020. Praha: MŠMT.

Št'astnová, P., Drahoňovská, P., 2012. Jak si žáci základnich a středních škol vybírají svou další vzdělávací nebo pracovní kariéru. Praha: Národní ústav pro vzdělávání.

Trexima, 2015. Analýza bariér vstupu žáků základních škol do technického vzdélávání. [online] at https://www.mpo.cz/assets/cz/prumysl/zpracovatelsky-prumysl/2017/5/Analyza-barier-technickeho-vzdelavani-naZS.pdf (accessed 15 January, 2020).

Trhlíková, J., Vojtěch, J., a ÚIovcová, H., 2008. Rozhodování žáků při volbě vzdělávací cesty a úspěšnost vstupu na trh práce. Praha: Národní ústav odborného vzdělávání.

UNESCO, 2011. UNESCO ICT Competency Framework for Teachers. [online] at https://unesdoc.unesco.org/ark:/48223/pf0000213475 (accessed 21 January, 2020).

Vuorikari, R., Punie, Y., Carretero Gomez S., \& Van den Brande, G., 2016. DigComp 2.0: The Digital Competence Framework for Citizens. Update Phase 1: The Conceptual Reference Model. Luxembourg Publication Office of the European Union. doi:10.2791/11517

World Economic Forum 2016. The future jobs: skills and workforce strategy for the $4^{\text {th }}$ industrial revolution. Cologne: World Economic Forum. 